\title{
Surface charging of layered double hydroxides during dynamic interactions of anions at the interfaces
}

\author{
Zhi Ping Xu ${ }^{\mathrm{a}, *}$, Yonggang Jin ${ }^{\mathrm{a}}$, Shaomin Liu ${ }^{\mathrm{a}}$, Zheng Ping Hao ${ }^{\mathrm{b}}$, Gao Qing (Max) Lu ${ }^{\mathrm{a}, *}$ \\ a Australian Research Council (ARC) Centre of Excellence for Functional Nanomaterials, Australian Institute for Bioengineering and Nanotechnology and School of Engineering, \\ The University of Queensland, Brisbane, QLD 4072, Australia \\ ${ }^{\mathrm{b}}$ Research Center for Eco-Environmental Sciences, Chinese Academy of Sciences, Beijing 100085, PR China
}

\section{A R T I C L E I N F O}

\section{Article history:}

Received 12 May 2008

Accepted 26 June 2008

Available online 11 July 2008

\section{Keywords:}

Layered double hydroxide

Zeta potential

Surface charging

Anion adsorption and exchange

Point of zero charge

Agglomeration

\begin{abstract}
A B S T R A C T
In this research, we investigated the effect of dynamic anion adsorption/exchange on the surface charging property of $\mathrm{Mg}_{2} \mathrm{Al}-\mathrm{Cl}-\mathrm{LDH}$ and $\mathrm{Mg}_{2} \mathrm{Al}-\mathrm{CO}_{3}-\mathrm{LDH}$ particles that show the average zeta potential of 41 and $34 \mathrm{mV}$ in the as-prepared suspension, respectively. The addition of $\mathrm{NaCl}$ up to $3 \times 10^{-3} \mathrm{M}$ in the suspension does not obviously affect the zeta potential of both LDHs, which can be attributed to the less affinity of $\mathrm{Cl}^{-}$to $\mathrm{LDH}$. The introduction of $\mathrm{Na}_{2} \mathrm{CO}_{3}$ severely reduces the zeta potential at the $\mathrm{CO}_{3}^{2-}$ concentration higher than $1 \times 10^{-4} \mathrm{M}$, and to the negative value in both LDH systems at ca. $2 \times 10^{-3} \mathrm{M}$, which is presumably resulted from the exchange and the re-orientation of $\mathrm{CO}_{3}^{2-}$ in a tilt/vertical style on the surface. All four organic anions (dodecyl sulfate, folate, citrate and polyacrylate) also significantly affect the zeta potential of the LDH particles. At the lower concentrations of organic anionic groups $\left(<1 \times 10^{-4} \mathrm{M}\right)$, the zeta potential was slightly affected, i.e. limited exchange/adsorption. However, the concentration increasing to some point suddenly decreases and reverses the zeta potential of the LDH particles, which is presumably caused by the hydrophobic interactions that bind the hydrophobic hydrocarbon chains (especially in dodecyl sulfate) into the micelle-like bilayer bunches on the LDH surface. In addition, the effect of $\mathrm{pH}$ in 5.5-11.0 on the $\mathrm{LDH}$ particle surface charging is mainly reflected through the conversion of $\mathrm{CO}_{3}^{2-}$ to $\mathrm{HCO}_{3}^{-} / \mathrm{H}_{2} \mathrm{CO}_{3}$ when $\mathrm{pH}$ decreases from ca. 11 to 6 , with limited contribution from protonation/deprotonation and exchange/adsorption.
\end{abstract}

(c) 2008 Elsevier Inc. All rights reserved.

\section{Introduction}

Inorganic nanoparticles have been emerged as new non-viral delivery agents only in the recent decade, and there are many inorganic materials, such as calcium phosphate, gold, carbon materials, silicon oxide, iron oxide and layered double hydroxides (LDHs), being extensively investigated [1]. This is due to recognition of their versatile features suitable for cellular delivery, such as wide availability, rich surface functionality, good biocompatibility, potential capability of target delivery and sustained release [1]. In particular, LDH has been paid more attention as efficient delivery vehicles of drug, nucleotides/genes, biomedical and other functional molecules [2-4].

$\mathrm{LDH}$, also known as hydrotalcite-like material, can be found in nature as minerals and readily synthesized in the laboratory, with majority adhering to the general formula $\left[\mathrm{M}_{1-x}^{\mathrm{II}} \mathrm{M}_{x}^{\mathrm{III}}\right.$ $\left.(\mathrm{OH})_{2}\right]^{x+}\left(\mathrm{A}^{n-}\right)_{x / n} \cdot m \mathrm{H}_{2} \mathrm{O}$, where $\mathrm{M}^{\mathrm{II}}$ represents a divalent metal cation, $\mathrm{M}^{\mathrm{III}}$ a trivalent metal cation and $\mathrm{A}^{n-}$ an anion. Struc-

\footnotetext{
* Corresponding authors. Fax: +61 733363973.

E-mail addresses: gordonxu@uq.edu.au (Z.P. Xu), maxlu@uq.edu.au (G.Q.(M.) Lu).
}

turally, LDHs consist of cationic brucite-like layers and interlayer anions as well as water molecules. In the brucite-like layer $\left[\mathrm{M}^{\mathrm{II}}(\mathrm{OH})_{2}\right]$, the partial substitution of $\mathrm{M}^{\mathrm{II}}$ by $\mathrm{M}^{\mathrm{III}}$ leads to a positive charge $\left(\left[\mathrm{M}_{1-x}^{\mathrm{II}} \mathrm{M}_{x}^{\mathrm{III}}(\mathrm{OH})^{2}\right]^{x+}\right)$, which is neutralized by the interlayer exchangeable anion $\left[\left(\mathrm{A}^{n-}\right)_{x / n}\right]$ while various amounts of water $\left(m \mathrm{H}_{2} \mathrm{O}\right)$ are hydrogen bonded to the hydroxide layers and/or to the interlayer anions [5,6], forming the 3-D layered structure.

LDH particles prepared in the laboratory are normally hexagonal platelets, with the lateral sizes varying from 50 to $1000 \mathrm{~nm}$ and the aspect ratio in 5-10, while they are severely agglomerated into aggregates with the sizes up to $10 \mu \mathrm{m}[7,8]$. Recently, we developed a reliable method with which the LDH platelet dimension can be well controlled in $50-300 \mathrm{~nm}$ and these platelets can be homogeneously dispersed in the aqueous suspension [8]. Therefore, if the LDH platelet dimension is controlled under $150-200 \mathrm{~nm}$, the cellular delivery of such LDH platelets should be efficient [9]. However, when we further carried out the delivery of supercoiled pEFeGFP plasmid (ca. $6.1 \mathrm{kbp}$ ) to various cell lines using these LDH particles, we noted that the delivery efficiency was rather low in comparison with the polymeric delivery vehicle [10]. Many other papers reported the successful delivery of various gene segments 
[3,11-13], but the efficiency was much lower than the commercial polymeric agents $[1,3,10,13]$. The low delivery efficiency, in our belief, is due to aggregation of LDH-DNA hybrid particles into large aggregates during preparing the LDH-DNA nanohybrid suspension and mixing it to the culture medium.

It is well known that dispersion and aggregation of any particles in the suspension are related to their zeta potential [14]. Because inorgano-LDH particles normally have a zeta potential of 30-50 $\mathrm{mV}$, they can be well dispersed in the suspension with the suitable methods, such as hydrothermal treatment [15]. However, this high positive zeta potential is reduced when the particles are interacting with gene segments, or with organic/inorganic salts in solution, which could finally lead to agglomeration and sedimentation. Therefore, in this research, we dynamically investigated the surface charging of fully dispersed LDH particles in aqueous suspension when the organic/inorganic anions at various concentrations are interacting on the particle surface in order that we understand the surface charging and agglomeration of LDH particles in the salt solution, such as phosphate buffer saline solution.

\section{Experimental}

\subsection{Preparation of $L D H$ materials}

$\mathrm{Mg}_{2} \mathrm{Al}-\mathrm{Cl}-\mathrm{LDH}$ and $\mathrm{Mg}_{2} \mathrm{Al}-\mathrm{CO}_{3}-\mathrm{LDH}$ particle suspensions were prepared with a quick precipitation and subsequent hydrothermal treatment $[8,15]$. In brief, $3.0 \mathrm{mmol}$ of $\mathrm{MgCl}_{2} \cdot 6 \mathrm{H}_{2} \mathrm{O}$ (>98\%, Aldrich) and $1.0 \mathrm{mmol}$ of $\mathrm{AlCl}_{3} \cdot 6 \mathrm{H}_{2} \mathrm{O}$ (>98\%, Aldrich) were dissolved in $10 \mathrm{~mL}$ deionized water. This salt solution was then rapidly added to a basic solution $(40 \mathrm{~mL})$ containing $6.0 \mathrm{mmol}$ of $\mathrm{NaOH}(>97 \%$, Ajax Finechem) within $5 \mathrm{~s}$ to generate the precipitate of $\mathrm{Mg}_{2} \mathrm{Al}-\mathrm{Cl}-$ LDH. After stirring for 10 min in $\mathrm{N}_{2}$ stream at room temperature, the precipitate was collected via centrifugation and further washed twice. Henceforth, the washed precipitate was manually dispersed in $40 \mathrm{~mL}$ of deionized water and placed in a $45 \mathrm{~mL}$ autoclave with Teflon linen, followed by hydrothermal treatment at $100^{\circ} \mathrm{C}$ in an oven for $16 \mathrm{~h}$ to give the suspension of $\mathrm{Mg}_{2} \mathrm{Al}-\mathrm{Cl}-\mathrm{LDH}$ particles (regarded as 'salt-free' suspension).

Similarly, $2.0 \mathrm{mmol}$ of $\mathrm{MgCl}_{2} \cdot 6 \mathrm{H}_{2} \mathrm{O}$ and $1.0 \mathrm{mmol}$ of $\mathrm{AlCl}_{3} \cdot 6 \mathrm{H}_{2} \mathrm{O}$ were dissolved in $10 \mathrm{~mL}$ deionized water, which was then rapidly added to a basic solution $(40 \mathrm{~mL})$ containing $6.0 \mathrm{mmol}$ of $\mathrm{NaOH}$ and $0.6 \mathrm{mmol}$ of $\mathrm{Na}_{2} \mathrm{CO}_{3}$ (>99\%, Ajax Finechem) within $5 \mathrm{~s}$ to generate the precipitate of $\mathrm{Mg}_{2} \mathrm{Al}-\mathrm{CO}_{3}-\mathrm{LDH}$ and stirred for $10 \mathrm{~min}$ at room temperature. The stirred mixture was post-treated in the same way as above to generate the suspension of $\mathrm{Mg}_{2} \mathrm{Al}-\mathrm{CO}_{3}-\mathrm{LDH}$ particles.

\subsection{Materials characterization}

$\mathrm{Mg}_{2} \mathrm{Al}-\mathrm{Cl}-\mathrm{LDH}$ and $\mathrm{Mg}_{2} \mathrm{Al}-\mathrm{CO}_{3}-\mathrm{LDH}$ materials were identified by X-ray powder diffraction (XRD), using a Bruker D8 Advance Research X-ray diffractometer with copper $K_{\alpha}$ radiation $(\lambda=0.15418 \mathrm{~nm})$ at a scanning rate of $1.2^{\circ} /$ min over a $2 \theta$ range of $8^{\circ}-65^{\circ}$. The LDH samples were mounted on glass slides in the thin film form by dropping a few drops of the as-prepared LDH particle suspension. The instrument was calibrated with the crystalline silicon and the basal spacing was determined from the characteristic diffraction peaks. Fourier transform infrared (FTIR) spectra were acquired over the range of $4000-400 \mathrm{~cm}^{-1}$ with 40 scans at a resolution of $4.0 \mathrm{~cm}^{-1}$ on a Nicolet 6700 FTIR by measuring the $\mathrm{KBr}$ pellet containing 1-2 wt\% of the LDH sample.

Photon correlation spectroscopy (PCS, Nanosizer Nano ZS, Malvern Instruments) was used to analyze the particle size distribution of the LDH suspensions from 0.6 to $6000 \mathrm{~nm}$ at $25^{\circ} \mathrm{C}$, in which the peak position was automatically calculated. The water refractive index (RI) of 1.33 and the water viscosity of $0.8872 \mathrm{cP}$ were employed while the RI of LDH materials was arbitrarily assigned 1.55 .

The transmission electron microscopic (TEM) images were recorded on a JEOL JSM-2010 transmission electron microscope (TEM) at an acceleration voltage of $200 \mathrm{kV}$. For TEM imaging, a droplet of the diluted as-prepared LDH particle suspension (1:10) was dropped on a copper grid coated with the holey carbon film.

\subsection{Zeta potential monitoring during titrations}

Zeta potentials of the two diluted LDH suspensions were also measured using the Zetasizer Nano ZS (Malvern Instruments) with the water RI of 1.33, the water dielectric constant of 78.55 and the water viscosity of $0.8872 \mathrm{cP}$. In order to dynamically monitor the change of the zeta potential when an organic/inorganic salt or acid/base solution was continuously mixed with the LDH suspension, the measurement was performed using the MPT-2 Autotitrator associated to Zetasizer Nano ZS where the titration system was well sealed. In the first step, each LDH suspension of $1.0 \mathrm{~mL}$ was diluted with $9.0 \mathrm{~mL}$ of deionized water in a $25 \mathrm{~mL}$ sample container which was then attached to the MPT-2 Autotitrator. The diluted LDH suspension was kept at $25^{\circ} \mathrm{C}$ and started to circulate into the zeta cell. The zeta potential was monitored and became stabilized after circulation for 3-5 min. After stabilization, the zeta potential was read by accumulating 30 times, which was regarded as the zeta potential of the as-prepared LDH particles.

In the next step, the diluted LDH suspension was injected with dilute $\mathrm{NaOH}$ solution $(0.01 \mathrm{M})$ to adjust $\mathrm{pH}$ of the $\mathrm{LDH}$ suspension (ca. 9.0) to ca. 11.0 via the autotitration set-up. The zeta potential and the exact $\mathrm{pH}$ were read after the reading was stabilized. To monitor the zeta potential changing with $\mathrm{pH}$, the dilute $\mathrm{HCl}(0.01$ $\mathrm{M}$ ) was automatically injected to the $\mathrm{LDH}$ suspension to change $\mathrm{pH}$ to a pre-designed value in the range from 11.0 to 5.5. After injection, the suspension was circulated, and zeta potential was measured only after the zeta potential reading became stable. Then the injection of dilute $\mathrm{HCl}$ solution was repeated to the next $\mathrm{pH}$ until to 5.5. The reverse autotitration from $\mathrm{pH} 5.5$ to 11.0 was continued with injecting dilute $\mathrm{NaOH}$ solution in the similar way, with recording the zeta potential at each $\mathrm{pH}$.

Alternatively, an inorganic/organic salt solution was injected to the diluted LDH suspension to investigate the dynamic exchange/adsorption of the inorganic/organic anion on the LDH particle surface at $25^{\circ} \mathrm{C}$ through monitoring the zeta potential change. For example, dilute $\mathrm{NaCl}(0.01 \mathrm{M})$ or $\mathrm{Na}_{2} \mathrm{CO}_{3}(0.01 \mathrm{M})$ solution was added to the $\mathrm{LDH}$ suspension with $\left[\mathrm{Cl}^{-}\right]$or $\left[\mathrm{CO}_{3}^{2-}\right]$ varying from $1.0 \times 10^{-5}$ to $3.0 \times 10^{-3} \mathrm{M}$. At each pre-designed concentration point, the LDH suspension was circulated until the zeta potential reading was stable. In comparison, some organic anions were selected, including dodecyl sulfate (singly charged), folate (doubly charge), citrate (triply charged) and poly(acrylate) (multiply charged, $\mathrm{MW}=\sim 10,000$ ). Their sodium salt solutions were made and auto-titrated to increase the anionic group (functionality: $\mathrm{COO}^{-}$or $\mathrm{R}_{-} \mathrm{OSO}_{3}^{-}$) concentration from $1.0-3.0 \times 10^{-5}$ to 3.0-9.0 $\times 10^{-3} \mathrm{M}$, while the zeta potential at each point was monitored.

\section{Results}

\subsection{Physicochemcal features of $L D H$ particles}

Two as-prepared LDH suspensions look homogeneous and very transparent, with the LDH crystallite particles being well suspended in solution. As shown in Fig. 1, there is one distribution band for each $\mathrm{LDH}$ suspension. For instance, $\mathrm{Mg}_{2} \mathrm{Al}-\mathrm{Cl}-\mathrm{LDH}$ particles have the hydrodynamic diameters exclusively in $30-250 \mathrm{~nm}$ 


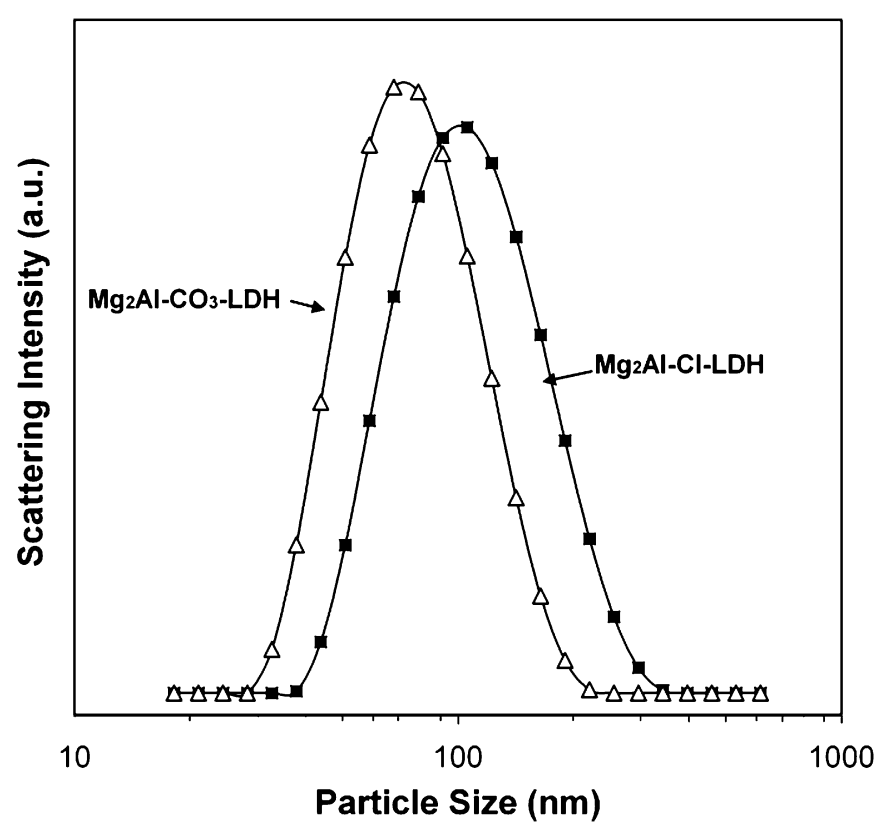

Fig. 1. Particle size distribution of the as-prepared $\mathrm{Mg}_{2} \mathrm{Al}-\mathrm{CO}_{3}-\mathrm{LDH}$ and $\mathrm{Mg}_{2} \mathrm{Al}-$ $\mathrm{Cl}$-LDH suspensions.

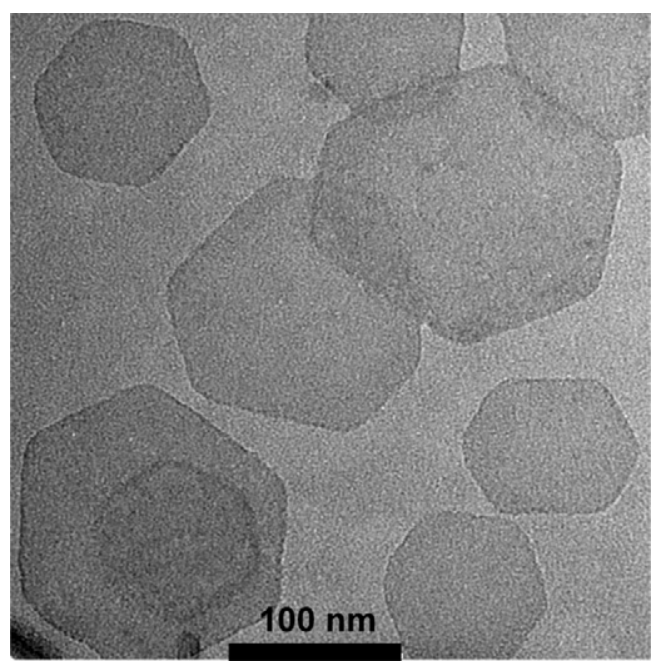

(A)

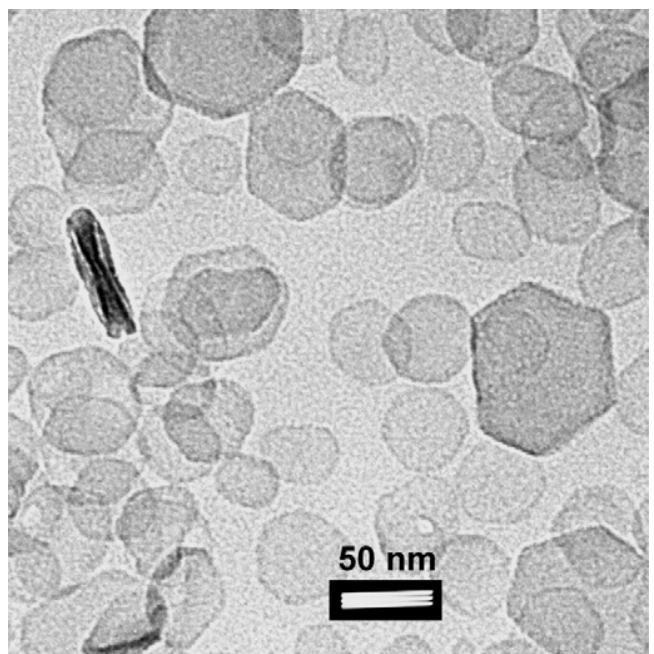

(B)

Fig. 2. TEM images of (A) $\mathrm{Mg}_{2} \mathrm{Al}-\mathrm{Cl}-\mathrm{LDH}$ and (B) $\mathrm{Mg}_{2} \mathrm{Al}-\mathrm{CO}_{3}-\mathrm{LDH}$ particles.

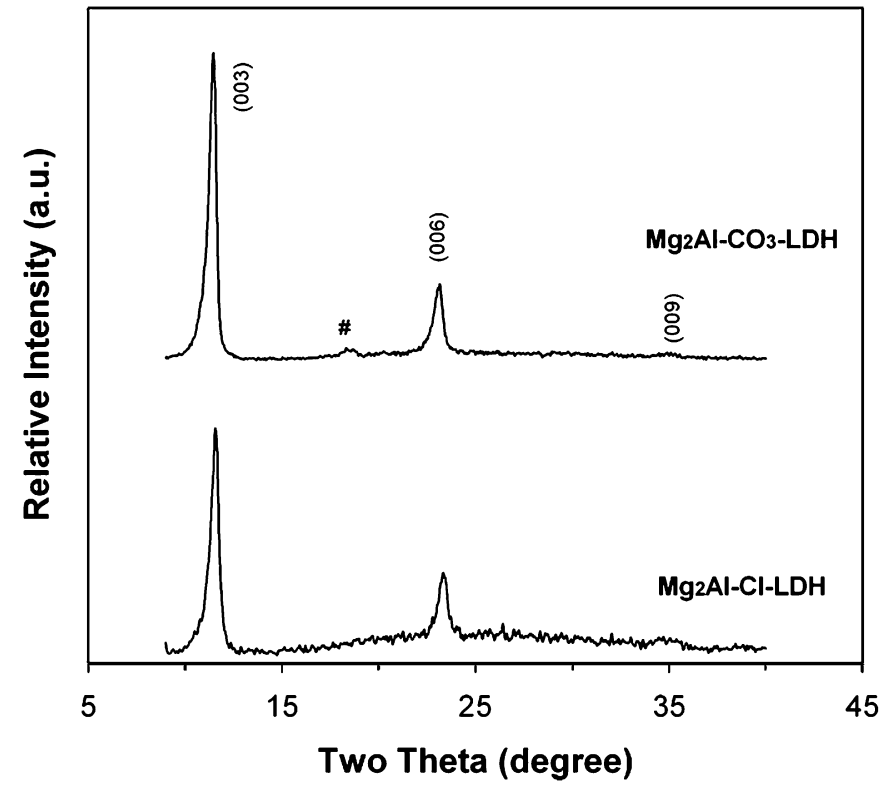

(A)

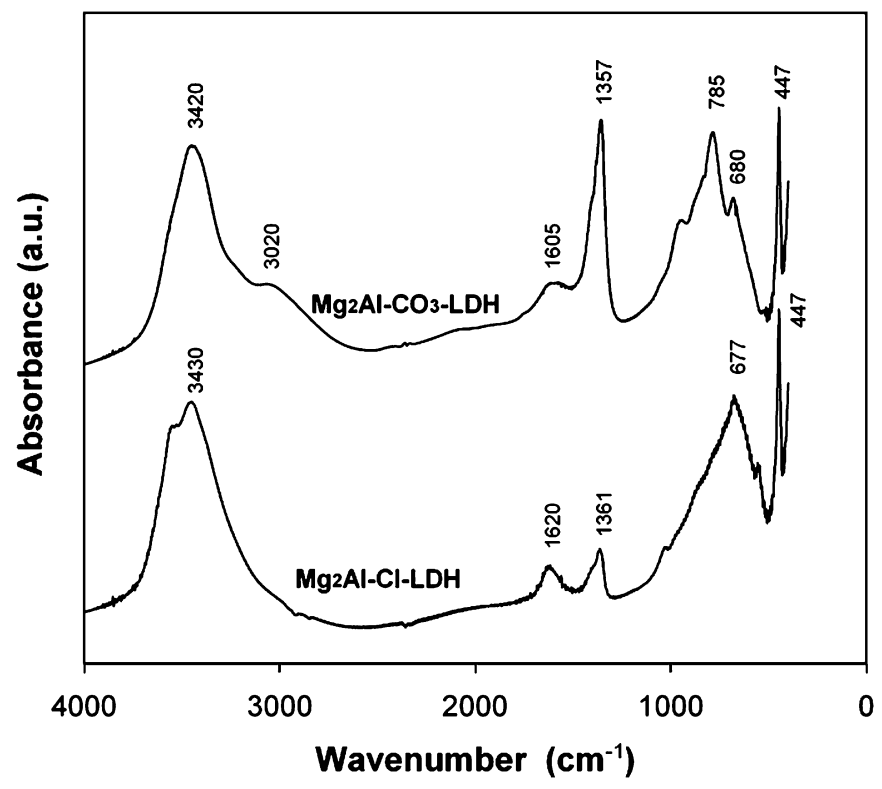

(B)

Fig. 3. XRD patterns (A) and FTIR spectra (B) of $\mathrm{Mg}_{2} \mathrm{Al}-\mathrm{CO}_{3}-\mathrm{LDH}$ and $\mathrm{Mg}_{2} \mathrm{Al}-\mathrm{Cl}-\mathrm{LDH}$ materials.

with the peak at $115 \mathrm{~nm}$, while $\mathrm{Mg}_{2} \mathrm{Al}-\mathrm{CO}_{3}-\mathrm{LDH}$ particles are distributed around ca. $80 \mathrm{~nm}$ in the size range of $25-180 \mathrm{~nm}$. The hydrodynamic diameters are relatively similar to the lateral dimension of LDH platelets measured in TEM images (Fig. 2). Fig. 2 shows that both LDH particles are hexagonally sheet-like. The lateral diameters of $\mathrm{Mg}_{2} \mathrm{Al}-\mathrm{Cl}-\mathrm{LDH}$ platelets are mostly $80-200 \mathrm{~nm}$ and those of $\mathrm{Mg}_{2} \mathrm{Al}-\mathrm{CO}_{3}-\mathrm{LDH}$ platelets are $30-100 \mathrm{~nm}$. It seems that $\mathrm{Mg}_{2} \mathrm{Al}-\mathrm{CO}_{3}-\mathrm{LDH}$ platelets are relatively thicker than $\mathrm{Mg}_{2} \mathrm{Al}-$ $\mathrm{Cl}-\mathrm{LDH}$, due to the stronger affinity of $\mathrm{CO}_{3}^{2-}$ to $\mathrm{LDH}$ that causes more hydroxide layers to stack on top of one another [16].

The XRD patterns of LDH materials deposited on the glass plates in the thin film form exhibit the typical layered features and demonstrate a good crystallinity, as shown in Fig. 3A. The d-spacing is $0.772 \mathrm{~nm}$ for $\mathrm{Mg}_{2} \mathrm{Al}-\mathrm{Cl}$-LDH and $0.764 \mathrm{~nm}$ for $\mathrm{Mg}_{2} \mathrm{Al}-\mathrm{CO}_{3}-\mathrm{LDH}$, respectively, quite similar to those reported elsewhere [6]. Very interestingly, only basal diffractions [(003), (006) and (009), etc.] are observable in the patterns while other non- 


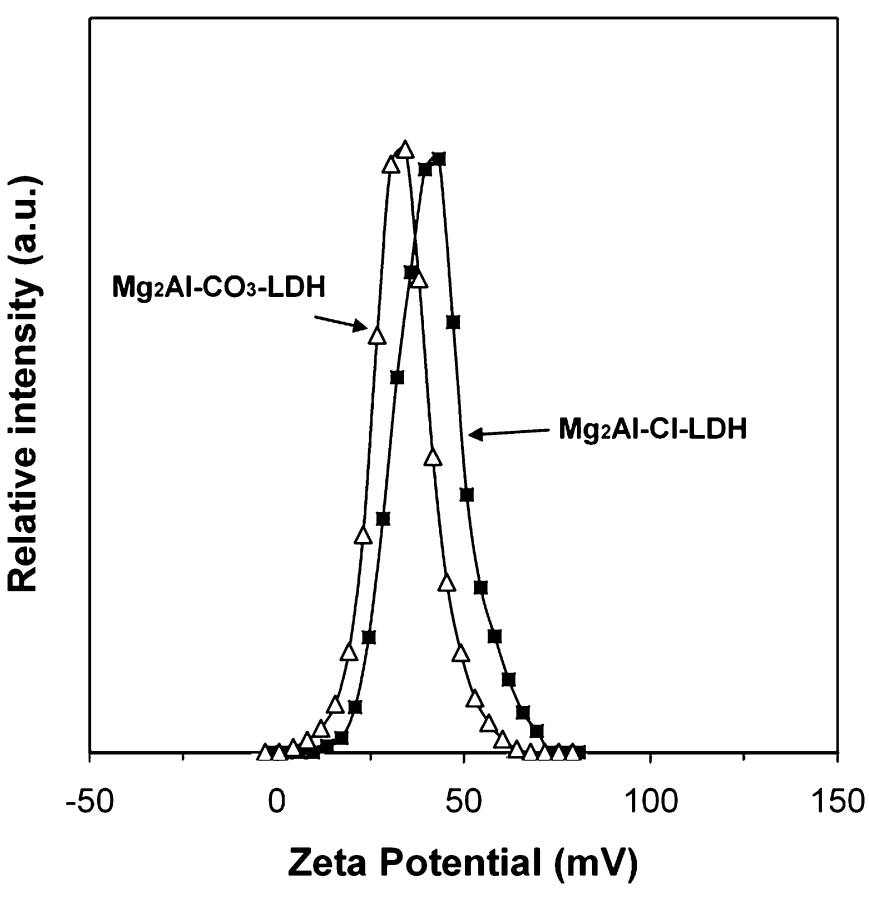

Fig. 4. Zeta potential distribution of $\mathrm{Mg}_{2} \mathrm{Al}-\mathrm{CO}_{3}-\mathrm{LDH}$ and $\mathrm{Mg}_{2} \mathrm{Al}-\mathrm{Cl}-\mathrm{LDH}$ particles.

basal characteristic diffractions, such as (015), (018), (110) and (113), are not. This indicates that the LDH platelets are flatly laid on the glass plate after drying, as also seen in TEM images where LDH platelets are almost all flatly laid on the sample support. The full width at the half maximum (FWHM) of peaks (003) and (006) suggests that the thickness of both LDH platelets is ca. $15 \mathrm{~nm}$ on average, as estimated by using the Debye-Scherrer equation without any correction [17]. Thus the aspect ratio is ca. 8 and 5 for $\mathrm{Mg}_{2} \mathrm{Al}-\mathrm{Cl}-\mathrm{LDH}$ and $\mathrm{Mg}_{2} \mathrm{Al}-\mathrm{CO}_{3}-\mathrm{LDH}$ platelets, respectively. In addition, elemental analysis gives the atomic ratio [Mg]/[Al] of $\sim 1.9$, slightly less than the designed value (2.0), attributed to more $\mathrm{Mg}^{2+}$ leaching than $\mathrm{Al}^{3+}$ from the hydroxide layers during hydrothermal treatment [18]. The leaching of more $\mathrm{Mg}^{2+}$ may also lead to formation of traces of gibbsite, as marked with \# in Fig. 3A. Thus, the nominal chemical formula of $\mathrm{Mg}_{2} \mathrm{Al}-\mathrm{Cl}-\mathrm{LDH}$ and $\mathrm{Mg}_{2} \mathrm{Al}-\mathrm{CO}_{3}-\mathrm{LDH}$ are approximately $\mathrm{Mg}_{1.9} \mathrm{Al}(\mathrm{OH})_{5.8} \mathrm{Cl} \cdot \mathrm{mH}_{2} \mathrm{O}$ and $\mathrm{Mg}_{1.9} \mathrm{Al}(\mathrm{OH})_{5.8}\left(\mathrm{CO}_{3}\right)_{0.5} \cdot n \mathrm{H}_{2} \mathrm{O}(m, n=2-4$ depending the drying conditions). Based on the metal contents, the LDH particle concentration is approximately $0.4 \mathrm{wt} \%$ in both as-prepared suspensions.

FTIR spectra in Fig. 3B are characteristic of $\mathrm{Mg}_{2} \mathrm{Al}-\mathrm{LDH}$ materials. For example, $\mathrm{Mg}_{2} \mathrm{Al}-\mathrm{CO}_{3}-\mathrm{LDH}$ is featured in the FTIR spectrum with a broad band at $3420 \mathrm{~cm}^{-1}\left(v_{\mathrm{OH}}\right)$, a shoulder at $3020 \mathrm{~cm}^{-1}$ ( $\nu_{\mathrm{OH}}$ for $\mathrm{O}-\mathrm{H}$ that interacts with $\mathrm{CO}_{3}^{2-}$ through $\mathrm{H}$-bond), a peak at $1605 \mathrm{~cm}^{-1}\left(\delta_{\mathrm{H}_{2} \mathrm{O}}\right)$, a strong peak at $1357 \mathrm{~cm}^{-1}\left[v\left(\mathrm{CO}_{3}^{2-}\right)\right]$ and bands at 785, 680 and $447 \mathrm{~cm}^{-1}$ (M-O vibrations and M-O$\mathrm{H}$ bending). $\mathrm{Mg}_{2} \mathrm{Al}-\mathrm{Cl}-\mathrm{LDH}$ shows the similar IR spectrum, but without the shoulder at $3020 \mathrm{~cm}^{-1}$, with a rather weak peak at $1361 \mathrm{~cm}^{-1}$ (due to $\mathrm{CO}_{3}^{2-}$ contamination from $\mathrm{CO}_{2}$ in air) and the band at $785 \mathrm{~cm}^{-1}$ shifting to $677 \mathrm{~cm}^{-1}$ [6,19-21]. In particular, the sharp peak at $447 \mathrm{~cm}^{-1}$ is the definite evidence of $\mathrm{Mg}_{2} \mathrm{Al}-\mathrm{LDHs}$ [19,21].

\subsection{Zeta potential of as-prepared $\mathrm{LDH}$ particles}

Zeta potentials of both types of LDH particles in the suspension are positive, and distributed from 20 to $65 \mathrm{mV}\left(\mathrm{Mg}_{2} \mathrm{Al}-\mathrm{Cl}-\mathrm{LDH}\right)$ and from 10 to $55 \mathrm{mV}\left(\mathrm{Mg}_{2} \mathrm{Al}-\mathrm{CO}_{3}-\mathrm{LDH}\right)$, as shown in Fig. 4. The distribution of the zeta potentials indicates that the LDH surface is heterogeneous in terms of the surface charge. For instance, the

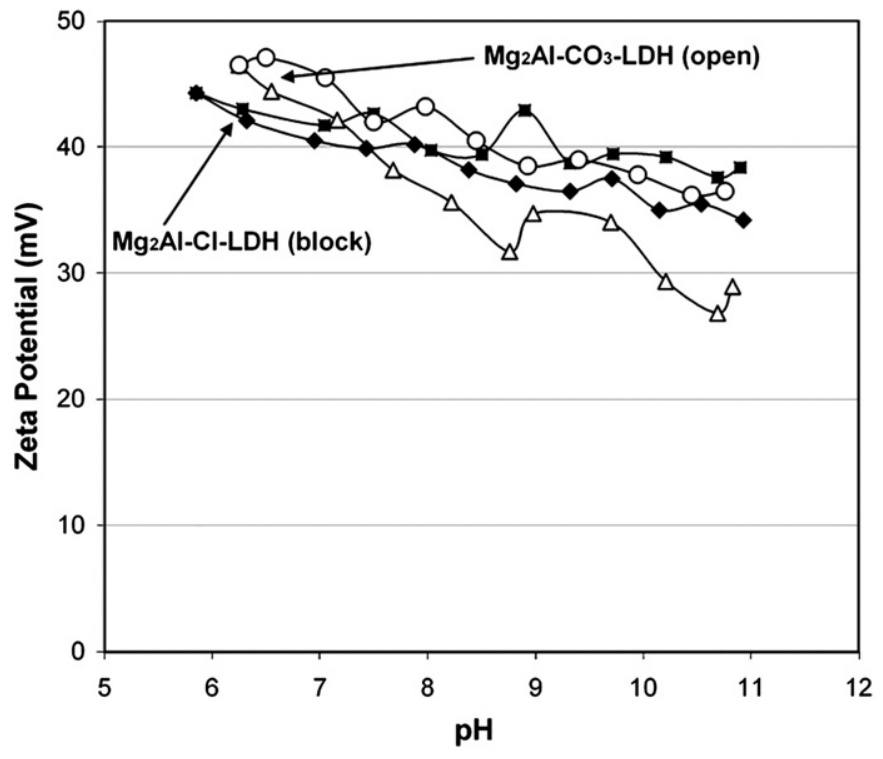

Fig. 5. Plots of the zeta potential of $\mathrm{Mg}_{2} \mathrm{Al}-\mathrm{CO}_{3}-\mathrm{LDH}$ (open triangle: forth; open circle: back) and $\mathrm{Mg}_{2} \mathrm{Al}-\mathrm{Cl}-\mathrm{LDH}$ (block square: forth; block diamond: back) particles vs the solution $\mathrm{pH}$.

charge density may be different on the c-plane and a/b-plane as well as on the edges and basal regions. The average zeta potential given by the instrument is 41 and $34 \mathrm{mV}$ for $\mathrm{Mg}_{2} \mathrm{Al}-\mathrm{Cl}-\mathrm{LDH}$ and $\mathrm{Mg}_{2} \mathrm{Al}-\mathrm{CO}_{3}-\mathrm{LDH}$, respectively. The average zeta potential was reported hereafter for the convenience of comparison.

The positive zeta potential of LDH particles is in principle attributed to the structural positive charge and the electric double layer on the LDH surface. Although the interior structural charges in the hydroxide layers are fully screened by the interlayer anions, the surface structural charges are not fully balanced by the adsorbed surface anions because of the existence of the electric double layer, i.e. Stern layer and diffusion layer. Since the surface adsorbed anions thermally vibrate and temporarily leave the Stern layer, there are always some anions statistically in the diffusion layer, and thus the LDH particle associated with the Stern layer is positively charged. The simulation reveals that ca. $4 \%$ of the surface structural charges are not balanced by $\mathrm{Cl}^{-}$in $\mathrm{Zn}_{2} \mathrm{Cr}-\mathrm{Cl}-\mathrm{LDH}$ [22]. In general, since $\mathrm{CO}_{3}^{2-}$ is more strongly adsorbed on the surface than $\mathrm{Cl}^{-}$, more surface $\mathrm{CO}_{3}^{2-}$ ions are kept in the Stern layer, i.e. less $\mathrm{CO}_{3}^{2-}$ in the diffusion layer, thus $\mathrm{Mg}_{2} \mathrm{Al}-\mathrm{CO}_{3}-\mathrm{LDH}$ particles show a smaller zeta potential (30-35 mV) than $\mathrm{Mg}_{2} \mathrm{Al}-\mathrm{Cl}-\mathrm{LDH}$ (40-50 mV), as reported [15]. In addition, the zeta potential of LDH particles in the suspension is little changed when the LDH concentration is varied in $0.1-4.0 \mathrm{wt} \%[15,23]$. Our observation was that there was 3-4 $\mathrm{mV}$ difference (i.e. similar to the measurement error) when $0.4 \mathrm{wt} \% \mathrm{LDH}$ suspension was diluted by 10 times in the titration experiments.

\section{3. $p H$ effect on the zeta potential}

As shown in Fig. 5, when $\mathrm{pH}$ of the LDH suspension is decreased from ca. 11 to 5.5 , the zeta potential of $\mathrm{Mg}_{2} \mathrm{Al}-\mathrm{Cl}-\mathrm{LDH}$ particles is only slightly increased from ca. 38 to $44 \mathrm{mV}$. When the back titration with dilute $\mathrm{NaOH}$ solution increases $\mathrm{pH}$ from 5.5 to 11.0 , the zeta potential of $\mathrm{Mg}_{2} \mathrm{Al}-\mathrm{Cl}-\mathrm{LDH}$ particles is slightly smaller at each corresponding pH (Fig. 5). The irreversibility of the zeta potential in the back and forth titration is expected to be mainly due to the ionic strength effect as well as the possible dissolution at $\mathrm{pH}<6$. For $\mathrm{Mg}_{2} \mathrm{Al}-\mathrm{LDH}$ system, the zeta potential reading became not stable when $\mathrm{pH}$ was tried to reach below 5 or above 12 , which is presumably caused by the dissolution of LDH 
at $\mathrm{pH}$ below 5 [24] or the $\mathrm{Al}^{3+}$ leaching from the layers at $\mathrm{pH}$ above 12 .

On the other hand, the zeta potential of $\mathrm{Mg}_{2} \mathrm{Al}-\mathrm{CO}_{3}-\mathrm{LDH}$ particles is increased from 30 to $45 \mathrm{mV}$ when $\mathrm{pH}$ is changed from 11 to 6.0 , more significantly at $\mathrm{pH}$ below 8 . Such a change trend with $\mathrm{pH}$ was also reported by Lagaly et al. for $\mathrm{MgAl}-\left(\mathrm{NO}_{3}, \mathrm{CO}_{3}, \mathrm{Cl}\right)-\mathrm{LDH}$ particles [25]. Apart from the effect of the ionic strength and dissolution at $\mathrm{pH}<6$, increasing the zeta potential of $\mathrm{Mg}_{2} \mathrm{Al}-\mathrm{CO}_{3}-\mathrm{LDH}$ is probably caused by the following consequent reactions during the $\mathrm{HCl}$ addition:

$\mathrm{CO}_{3}^{2-}+2 \mathrm{H}^{+} \Leftrightarrow \mathrm{HCO}_{3}^{-}+\mathrm{H}^{+} \Leftrightarrow \mathrm{H}_{2} \mathrm{CO}_{3} \Leftrightarrow \mathrm{H}_{2} \mathrm{O}+\mathrm{CO}_{2}$.

In solution, there is an equal amount of $\mathrm{CO}_{3}^{2-}$ and $\mathrm{HCO}_{3}^{-}$at $\mathrm{pH}$ $\approx 10.2$. As $\mathrm{pH}$ is lowered to $7-8$, more than $99 \% \mathrm{CO}_{3}^{2-}$ anions on the surface are theoretically transferred to $\mathrm{HCO}_{3}^{-}$. Since the in situ produced $\mathrm{HCO}_{3}^{-}$as well as the added $\mathrm{Cl}^{-}$have a less affinity for LDH than $\mathrm{CO}_{3}^{2-}$, thus these LDH particles exhibit a higher zeta potential at a lower $\mathrm{pH}$. Moreover, half $\mathrm{HCO}_{3}^{-}$are changed to $\mathrm{H}_{2} \mathrm{CO}_{3}$ at $\mathrm{pH} \approx 6.4$ that has a much less affinity for $\mathrm{LDH}$ and is readily replaced. Also note that the zeta potential is higher at each corresponding $\mathrm{pH}$ during the back titration of the $\mathrm{Mg}_{2} \mathrm{Al}-\mathrm{CO}_{3}-\mathrm{LDH}$ suspension with $\mathrm{NaOH}$ from $\mathrm{pH} 6$ to 11 (open circle in Fig. 5). This is because the surface $\mathrm{CO}_{3}^{2-}$ anions were already transferred to $\mathrm{H}_{2} \mathrm{CO}_{3}$ during the $\mathrm{HCl}$ titration to $\mathrm{pH} 6$ and replaced by $\mathrm{Cl}^{-}$, and thus the zeta potential became higher during the back titration with $\mathrm{NaOH}$.

During the dynamic titration, a few processes, i.e. protonation (Eq. (2)), deprotonation (Eq. (3)) and anion exchanges (Eqs. (3) and (4)) $[22,26]$, simultaneously take place and affect the zeta potential of $\mathrm{Mg}_{2} \mathrm{Al}-\mathrm{LDH}$ particles:

$\mathrm{M}-\mathrm{OH}+\mathrm{H}^{+} \Leftrightarrow \mathrm{M}-\mathrm{OH}_{2}^{+} \quad(\mathrm{M}=\mathrm{Mg}$ or $\mathrm{Al})$,

$\mathrm{M}-\mathrm{OH}+\mathrm{OH}^{-} \Leftrightarrow \mathrm{M}^{-} \mathrm{O}^{-}+\mathrm{H}_{2} \mathrm{O} \quad(\mathrm{M}=\mathrm{Mg}$ or $\mathrm{Al})$,

$\mathrm{LDH}^{+}-\mathrm{A}_{\text {(surface) }}^{-}+\mathrm{B}^{-} \Leftrightarrow \mathrm{LDH}^{+}-\mathrm{B}_{(\text {surface })}^{-}+\mathrm{A}^{-}$,

$\mathrm{LDH}^{+}-\mathrm{A}_{\text {(inner) }}^{-}+\mathrm{B}^{-} \Leftrightarrow \mathrm{LDH}^{+}-\mathrm{B}_{\text {(inner) }}^{-}+\mathrm{A}^{-}$.

Based on the relative small variation of the zeta potentials during the titration with dilute $\mathrm{HCl}$, the contribution of protonation (Eq. (2)) and deprotonation (Eq. (3)) is little significant and can be ignored when $\mathrm{pH}$ is $7-10$. When $\mathrm{pH}<7$, the surface hydroxide layer starts protonation (Eq. (2)) and dissolution [24]. This will increase the zeta potential of LDH particles [22], particularly for $\mathrm{Mg}_{2} \mathrm{Al}$-LDH system, as observed in this research. When $\mathrm{pH}>10$, deprotonation (Eq. (3)) takes place $[22,26]$ and results in a smaller zeta potential. In practice, we observed the decrease of the zeta potential by ca. $4 \mathrm{mV}$ when $\mathrm{pH}$ of LDH suspension was adjusted from ca. 9.0 (diluted LDH suspension) to ca. 11.0. This decrease is not significant but still detectable. In addition, the modeling results reveal that deprotonation of $\mathrm{ZnCr}-\mathrm{Cl}-\mathrm{LDH}$ particles would be significant at $\mathrm{pH}>10[22]$.

Since pH of LDH suspensions is varied only in 9.0-9.5 during the most titrations of inorganic and organic sodium salts, protonation/deprotonation of the hydroxide layers thus has a limited effect on the surface charging of LDH particles.

\subsection{Effect of inorganic salts on the zeta potential}

As reported by Lagaly [25] and Sun [23], $\mathrm{NaCl}$ salt in a certain range of concentrations does not significantly change the zeta potential of MgAl-LDH particles. The similar phenomenon was also observed in the current research, as shown in Fig. 6A. Except for some variation in the measurement, the zeta potential of both LDHs is almost constant when $[\mathrm{NaCl}]$ is increased from $1 \times 10^{-5}$ to $3 \times 10^{-3} \mathrm{M}$. It is acknowledged that the $[\mathrm{NaCl}]$ increase leads

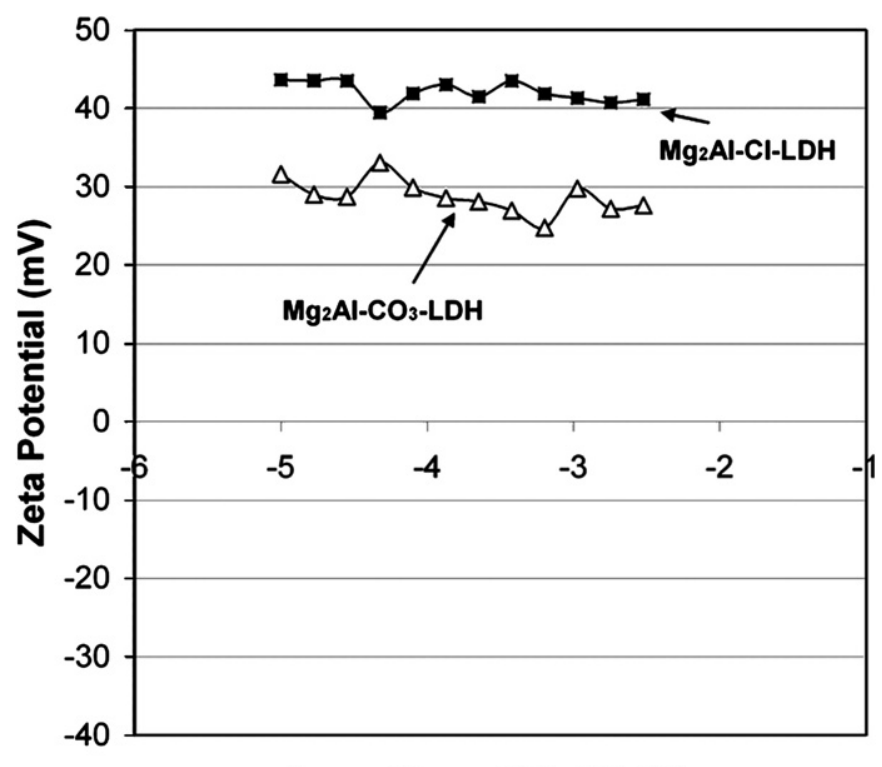

Logarithm of $[\mathrm{NaCl}](\mathrm{M})$

(A)

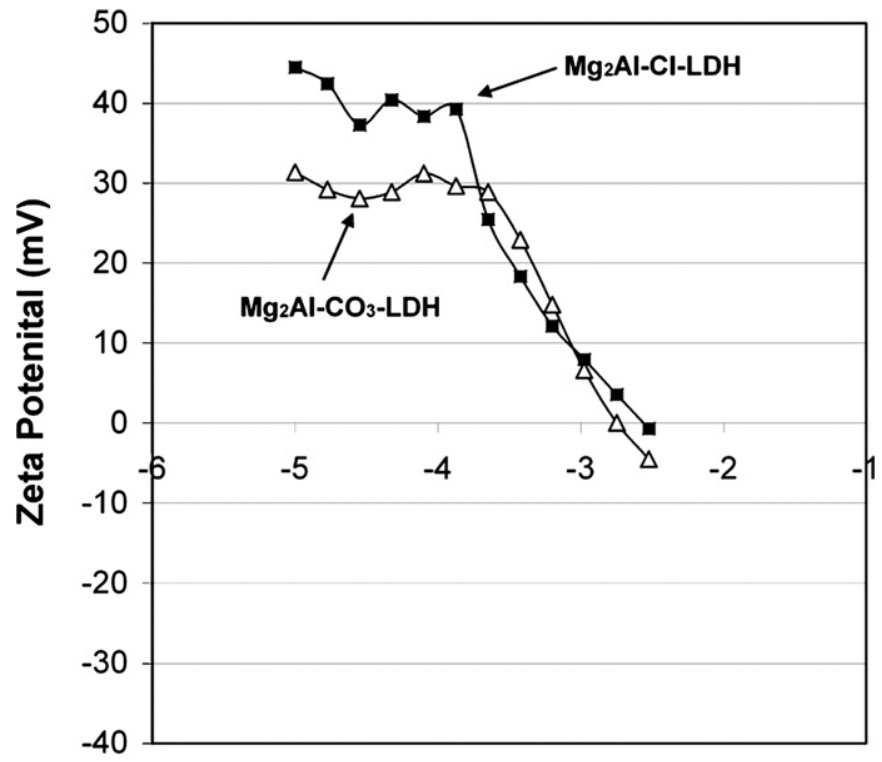

Logarithm of $\left[\mathrm{Na}_{2} \mathrm{CO}_{3}\right](\mathrm{M})$

(B)

Fig. 6. Plots of the zeta potential of $\mathrm{Mg}_{2} \mathrm{Al}-\mathrm{CO}_{3}-\mathrm{LDH}$ and $\mathrm{Mg}_{2} \mathrm{Al}-\mathrm{Cl}-\mathrm{LDH}$ particles vs the concentration of $(\mathrm{A}) \mathrm{NaCl}$ and (B) $\mathrm{Na}_{2} \mathrm{CO}_{3}$.

to the ionic strength increase, and slightly reduces the zeta potential $(3 \mathrm{mV})$. Such a decease in the zeta potential was reported to continue until $[\mathrm{NaCl}]=0.1 \mathrm{M}[25]$, however, the zeta potential was still positive even if $[\mathrm{NaCl}]=1-3 \mathrm{M}$ (unpublished work in this group). In sharp contrast, when $\left[\mathrm{Na}_{2} \mathrm{CO}_{3}\right]$ is added to more than $2 \times 10^{-4} \mathrm{M}$, the zeta potential of both LDHs starts to decrease rapidly and approaches the point of zero charge (PZC) at ca. $2 \times 10^{-3}$ M. This phenomenon was also reported by Lagaly et al. and agreed quantitatively (Table 1) [25]. Lagaly et al. also reported the similar relationship between the zeta potential and the concentration of $\mathrm{Na}_{2} \mathrm{SO}_{4}$ and $\mathrm{Na}_{2} \mathrm{HPO}_{4}$ [25].

During the titration, the surface anion exchange (Eq. (4)) is expected to affect the zeta potential of LDH particles to a less degree. It is well known that the exchange is mainly dependent on the affinity of $\mathrm{LDH}$ for anionic $\mathrm{A}^{-}$and $\mathrm{B}^{-}$as well as the relative 
Table 1

Concentration (M) of inorganic anions and organic functionalities to reach the point of zero charge (PZC) of two LDHs

\begin{tabular}{lll}
\hline & $\mathrm{Mg}_{2} \mathrm{Al}-\mathrm{Cl}-\mathrm{LDH}$ & $\mathrm{Mg}_{2} \mathrm{Al}-\mathrm{CO}_{3}-\mathrm{LDH}$ \\
\hline $\mathrm{OH}^{-}, \mathrm{Cl}^{-}$ & - & - \\
$\mathrm{CO}_{3}^{2-}$ & $2.2 \times 10^{-3}$ & $2.0 \times 10^{-3}$ \\
& & $\left(3.0 \times 10^{-3}\right.$ in Ref. [25]) \\
$\mathrm{C}_{12} \mathrm{H}_{25} \mathrm{OSO}_{3}^{-}$ & $2.1 \times 10^{-4}$ & $5.1 \times 10^{-4}$ \\
$\mathrm{COO}^{-}$in folate & $1.2 \times 10^{-3}$ & $1.1 \times 10^{-3}$ \\
$\mathrm{COO}^{-}$in citrate & $2.5 \times 10^{-3}$ & $2.9 \times 10^{-3}$ \\
$\mathrm{COO}^{-}$in poly(acrylate) & $1.4 \times 10^{-3}$ & $1.0 \times 10^{-3}$ \\
\hline
\end{tabular}

concentration of $\mathrm{A}^{-}$and $\mathrm{B}^{-}$in solution. The in situ kinetics investigation reveals that the anion exchange first occurs on the LDH particle edges, then on the basal plane and finally onto the interlayer via diffusion [27], all within a few minutes [27,28]. The sites $\left(\mathrm{A}^{-}\right.$in $\left.\mathrm{LDH}\right)$ available for the exchange on the surface and on the bulk can be estimated from the size and thickness of LDH particles. Approximately, the site concentration in the LDH suspension in this research $\left(\left[\mathrm{A}^{-}\right]\right)$is $8.0 \times 10^{-5} \mathrm{M}$ on the surface and $1.5 \times 10^{-3} \mathrm{M}$ on the bulk, respectively. Because $\mathrm{Cl}^{-}$has a less affinity to $\mathrm{LDH}$ than $\mathrm{CO}_{3}^{2-}$, so the $\mathrm{NaCl}$ titration to the $\mathrm{Mg}_{2} \mathrm{Al}_{-}-\mathrm{CO}_{3}-$ LDH suspension does not cause any noticeable anion exchange. The similar explanation can be also applied to the $\mathrm{NaCl}$ titration to the $\mathrm{Mg}_{2} \mathrm{Al}-\mathrm{Cl}-\mathrm{LDH}$ suspension although the $\left[\mathrm{Cl}^{-}\right]$concentration is higher. The slight decrease of the zeta potential is mainly due to the ionic strength that forces more anions to enter the Stern layer.

In contrast, when $\mathrm{Na}_{2} \mathrm{CO}_{3}$ solution was injected, the zeta potential of $\mathrm{Mg}_{2} \mathrm{Al}-\mathrm{Cl}-\mathrm{LDH}$ started to decrease and finally became negative at ca. $3 \times 10^{-3} \mathrm{M}$. This is first related to the exchange of nearly all surface and near-edge $\mathrm{Cl}^{-}$with $\mathrm{CO}_{3}^{2-}$ at $\left[\mathrm{Na}_{2} \mathrm{CO}_{3}\right]=1.0 \times 10^{-5}$ to $1.5 \times 10^{-4} \mathrm{M}$. At above $1.5 \times 10^{-4} \mathrm{M}$, the zeta potential sharply decrease and surprisingly the zeta potential of the $\mathrm{Mg}_{2} \mathrm{Al}-\mathrm{Cl}-\mathrm{LDH}$ particles became negative at $\left[\mathrm{Na}_{2} \mathrm{CO}_{3}\right]=\mathrm{ca} .3 \times 10^{-3} \mathrm{M}$. Even surprisingly, the zeta potential of $\mathrm{Mg}_{2} \mathrm{Al}-\mathrm{CO}_{3}-\mathrm{LDH}$ particles became also negative at $\left[\mathrm{Na}_{2} \mathrm{CO}_{3}\right]=\mathrm{ca} .2 \times 10^{-3} \mathrm{M}$. This seems to contradict to the fact that the zeta potential of salt-free $\mathrm{Mg}_{2} \mathrm{Al}-\mathrm{CO}_{3}-\mathrm{LDH}$ particles in the suspension is always positive. The zeta potential reversion suggests some other particular process happening with $\mathrm{CO}_{3}^{2-}$ because the $\mathrm{pH}\left(\mathrm{ca} .10 .5\right.$ at $\left[\mathrm{Na}_{2} \mathrm{CO}_{3}\right]=2 \times 10^{-3} \mathrm{M}$ ) and the ionic strength can only slightly reduce the zeta potential (at most by $5-10 \mathrm{mV}$ estimated from the data in Figs. 5 and $6 \mathrm{~A}$ ). We believe that the configuration of some adsorbed $\mathrm{CO}_{3}^{2-}$ on the $\mathrm{LDH}$ surface are forcedly changed to allow more $\mathrm{CO}_{3}^{2-}$ to be adsorbed at higher concentrations of $\mathrm{CO}_{3}^{2-}$. As shown in Fig. 7A, some flatly laid $\mathrm{CO}_{3}^{2-}$ ions ( $X$ in Fig. 7A) are forced to be tilt or vertical ( $Y$ in Fig. 7A), so that one $\mathrm{CO}_{3}^{2-}$ now does not screen two surface positive charges as usual, but screens only one positive surface charge. Therefore, the surface can hold more $\mathrm{CO}_{3}^{2-}$ and the particle is made negatively charged. Note that the tilt/vertical arrangement of $\mathrm{CO}_{3}^{2-}$ in the interlayer spacing was previously proposed by Ulibarri et al. [29] for $x=0.44$ in $\left[\mathrm{Ni}_{1-x} \mathrm{Al}_{x}(\mathrm{OH})_{2}\right]\left(\mathrm{CO}_{3}^{2-}\right)_{x / 2} \cdot n \mathrm{H}_{2} \mathrm{O}$. Since $\mathrm{CO}_{3}^{2-}$ anions are very crowded in the interlayer, they are forced to be tilt/vertical in the interlayer. Such a configurational rearrangement of $\mathrm{CO}_{3}^{2-}$ in the interlayer may also occur on the surface when the $\mathrm{CO}_{3}^{2-}$ concentration is high enough. If this postulation is true, then only ca. $4 \%$ of surface $\mathrm{CO}_{3}^{2-}$ doing so can make the surface negatively charged based on the simulation result that the net positive charge density is $0.01 \mathrm{C} / \mathrm{m}^{2}$ while the inherent surface charge density is $0.24 \mathrm{C} / \mathrm{m}^{2}$ [22]. In addition, this model can also explain the reverse effect of $\mathrm{Na}_{2} \mathrm{SO}_{4}$ and $\mathrm{Na}_{2} \mathrm{HPO}_{4}$ on the zeta potential at a similar concentration observed by Lagaly et al. [25]. In these two cases, the tetrahedronal anions $\left(\mathrm{SO}_{4}^{2-}\right.$ or $\left.\mathrm{HPO}_{4}^{2-}\right)$ can naturally stand on the surface to allow more anions to enter the Stern layer, and result in the PZC of LDH particles at an even lower anion concentration [25].

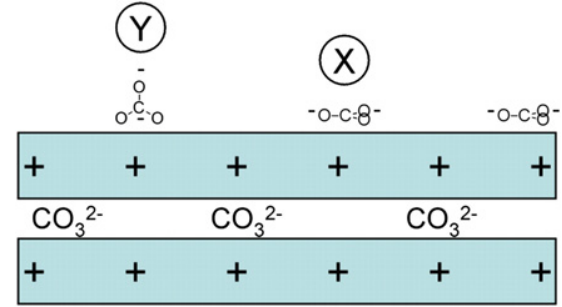

(A)

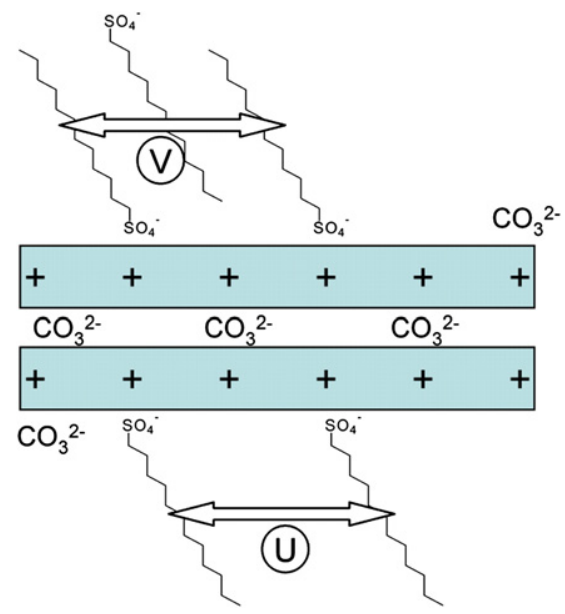

(B)

Fig. 7. Adsorption models of (A) carbonate and (B) dodecyl sulfate on the LDH surface.

\subsection{Effect of organic salts on the zeta potential}

Figs. 8A-8D demonstrate the zeta potential change of LDH particles with the concentration of various organic anions. To compare the effect of these organic anions on the similar base, the concentration is expressed as the anionic group concentration. In general, the zeta potential of LDH particles is slightly changed at the lower concentrations $\left(1 \times 10^{-5}\right.$ to ca. $\left.1-8 \times 10^{-4} \mathrm{M}\right)$, then has a steep decrease to the negative value in a narrow concentration range. For example, when dodecyl sulfate concentration was increased from $1.0 \times 10^{-5}$ to $3.8 \times 10^{-4} \mathrm{M}$, the zeta potential of $\mathrm{Mg}_{2} \mathrm{Al}-\mathrm{CO}_{3}-\mathrm{LDH}$ particles was decreased from 24.5 to $16.2 \mathrm{mV}$. However, as the concentration was further increased from $3.8 \times 10^{-4}$ to $6.3 \times 10^{-4} \mathrm{M}$, the zeta potential was reversed from 16.2 to $-14.5 \mathrm{mV}$ (Fig. 8A). The phenomenon is very much similar for all other cases (Figs. 8B8D) except for the titration with dodecyl sulfate to the $\mathrm{Mg}_{2} \mathrm{Al}-\mathrm{Cl}-$ LDH suspension. At around $1.0 \times 10^{-4} \mathrm{M}$ of dodecyl sulfate, the zeta potential started to sharply decrease and then changed to a negative value as the concentration increased to $2.0 \times 10^{-4} \mathrm{M}$.

As summarized in Table 1, the concentration of organic functionalities that leads to the point of zero charge (PZC) is similar $\left(1.0-2.9 \times 10^{-3} \mathrm{M}\right)$ except for dodecyl sulfate. The PZC concentration of dodecyl sulfate $\left(2.1-5.1 \times 10^{-4} \mathrm{M}\right)$ is significantly lower, which can be ascribed to the higher affinity of its sulfate group $\left(-\mathrm{OSO}_{3}^{-}\right)$than carboxylate $\left(\mathrm{COO}^{-}\right)$and in particular to the stronger hydrophobic interactions between the long hydrocarbon chains (dodecyl, $-\mathrm{C}_{12} \mathrm{H}_{25}$ ). As schematically outlined in Fig. 7B, sulfate group can readily replace the surface $\mathrm{Cl}^{-}$in $\mathrm{Mg}_{2} \mathrm{Al}-\mathrm{Cl}$-LDH particles, starting on the edge and then on the basal plane [27]. When the concentration of dodecyl sulfate is increased to $1 \times 10^{-4} \mathrm{M}$, most surface $\mathrm{Cl}^{-}\left(8.0 \times 10^{-5} \mathrm{M}\right)$ are exchanged. Under this assumption, the hydrocarbons chains are aligned to face the water, forming a tentative high-tension surface (tailing region of $U$ in Fig. 7B). To release the surface tension, the further injected dodecyl sulfate will interact with these hydrocarbon chains via hydrophobic 


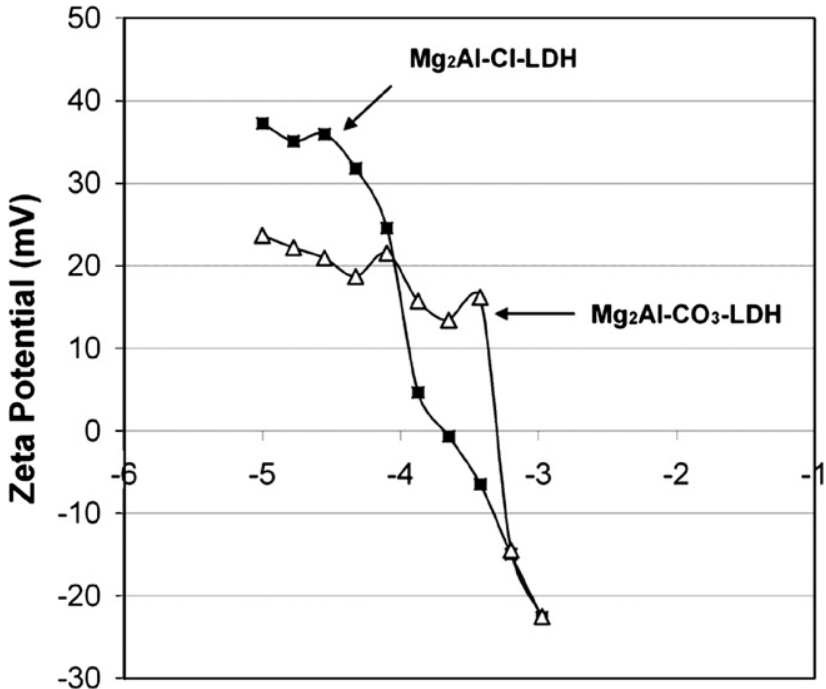

Logarithm of $\left[\mathrm{C}_{12} \mathrm{H}_{25} \mathrm{OSO}{ }_{3} \mathrm{Na}\right](\mathrm{M})$

(A)

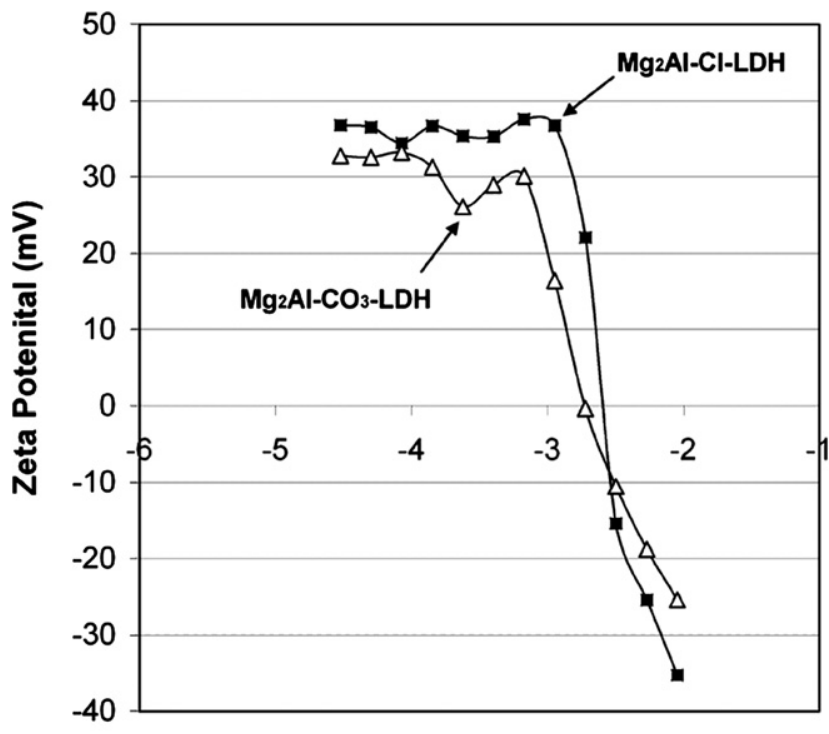

Logarithm of [COO-] in Citrate (M)

(C)

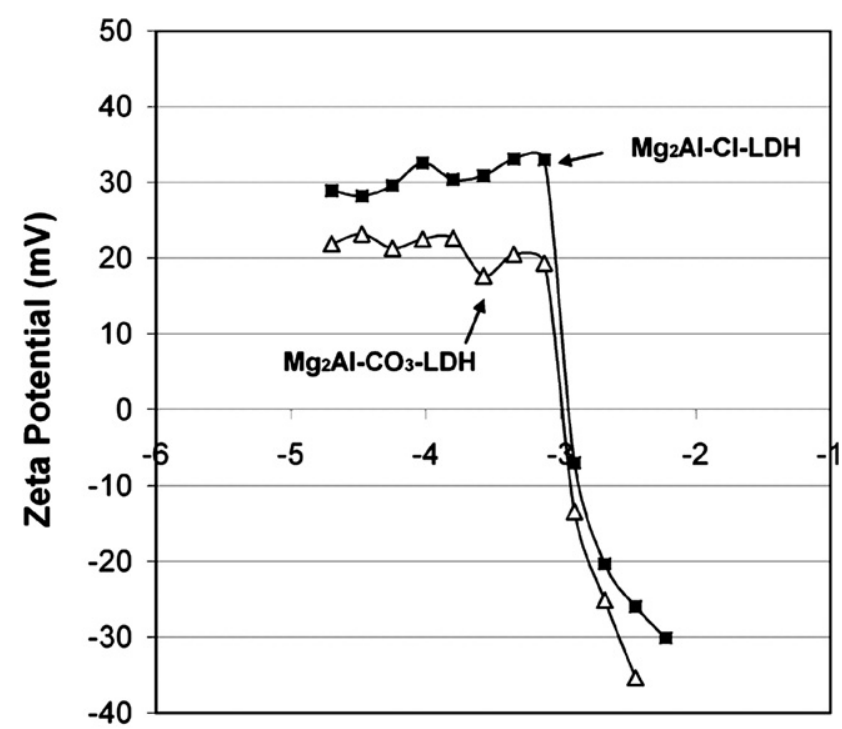

Logarithm of [COO-] in Folate (M)

(B)

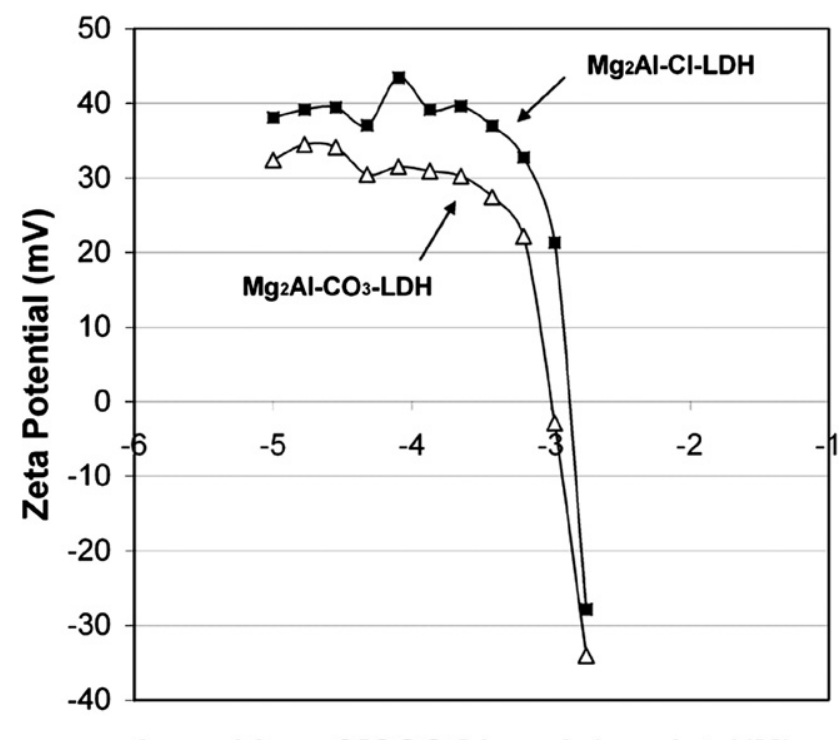

Logarithm of [COO-] in poly(acrylate)(M)

(D)

Fig. 8. Plots of the zeta potential of $\mathrm{Mg}_{2} \mathrm{Al}-\mathrm{CO}_{3}-\mathrm{LDH}$ and $\mathrm{Mg}_{2} \mathrm{Al}-\mathrm{Cl}-\mathrm{LDH}$ particles vs the concentration of (A) dodecyl sulfate, (B) folate, (C) citrate and (D) polyacrylate.

forces to form the micelle-like structure, such as the inter-digitated bilayer (region $\mathrm{V}$ in Fig. 7B). The formation of such a bilayer structure (micellization), or say, the organic species self-assembly on the particle surface, results in the negatively charged surface when ca. $4 \%$ more dodecyl sulfates are micellized on the surface.

In the case of $\mathrm{Mg}_{2} \mathrm{Al}-\mathrm{CO}_{3}-\mathrm{LDH}$, as $\mathrm{CO}_{3}^{2-}$ has a higher affinity for LDH than $\mathrm{Cl}^{-}$, its exchange with dodecyl sulfates can only significantly take place at a higher concentration $\left(3-4 \times 10^{-4} \mathrm{M}\right)$, and as a result, its PZC concentration $\left(5.1 \times 10^{-4} \mathrm{M}\right)$ is much higher than that in the case of $\mathrm{Mg}_{2} \mathrm{Al}-\mathrm{Cl}-\mathrm{LDH}\left(2.1 \times 10^{-4} \mathrm{M}\right)$. Note that the hydrophobic interactions between the long hydrocarbon chains have great contribution to the affinity of the organic anions to LDH [30], as reported for dodecylbenzene sulfonate that has an affinity comparable with $\mathrm{CO}_{3}^{2-}$ [31]. The hydrophobic interactions inter-connect many dodecyl chains into a bunch ( $\mathrm{V}$ in Fig. 7B) so that each organic anion shows a stronger affinity to $\operatorname{LDH}[30,31]$.

For the other three organic anions, the PZC concentration is much higher, which can be ascribed to two factors: (i) $-\mathrm{COO}^{-}$ group has a less affinity than $-\mathrm{OSO}_{3}^{-}$[32], so that the adsorption/exchange occurs at a higher concentration. This is evidenced by the fact that the zeta potential only significantly decreases at above $0.8-1.0 \times 10^{-3} \mathrm{M}$ of anionic groups; and (ii) the hydrophobic interactions among the short hydrocarbon chains or small hydrocarbon regions are much weaker than those among the straight dodecyl chains $\left(-\mathrm{C}_{12} \mathrm{H}_{25}\right)$, so that the micellization occurs at a high concentration. However, each of these anions has two or more anionic groups in one moiety, which helps to readily negatively charge the LDH particles because one or more anionic groups can directly face to the aqueous phase from the LDH particle surface. Therefore, even the affinity of $-\mathrm{COO}^{-}$group to $\mathrm{LDH}$ is weaker than $\mathrm{Cl}^{-}$and $\mathrm{CO}_{3}^{2-}, 1$ a small extra portion of exchange/adsorption ( $>4 \%$ ) is enough to make the $\mathrm{LDH}$ particles negatively charged.

\footnotetext{
1 Note: In the exchange of $\mathrm{LDH}-\mathrm{Cl}$ with $\mathrm{CH}_{3} \mathrm{COO}^{-}$, we found that the exchange degree is very small in one exchange experiment. If we continue to exchange for 34 times (exchange-separation, then exchange-separation, etc.), significant amount
} 
It is worth mentioning that when the zeta potential is down to close to zero, the LDH particles severely agglomerate. In general, the $\mathrm{LDH}$ particles start to aggregate at a salt concentration just around the PZC concentration [25] that is also called as the critical coagulation concentration.

\section{Conclusions}

In conclusion, the dynamic effect of $\mathrm{pH}$, inorganic and organic salts on the surface charging of $\mathrm{Mg}_{2} \mathrm{Al}-\mathrm{Cl}-\mathrm{LDH}$ and $\mathrm{Mg}_{2} \mathrm{Al}-\mathrm{CO}_{3}-$ $\mathrm{LDH}$ particles has been investigated. The decrease of $\mathrm{pH}$ from 11.0 to 5.5 has little effect on the zeta potential of $\mathrm{Mg}_{2} \mathrm{Al}-\mathrm{Cl}-\mathrm{LDH}$ but significantly increases that of $\mathrm{Mg}_{2} \mathrm{Al}-\mathrm{CO}_{3}-\mathrm{LDH}$ particles due to the conversion of $\mathrm{CO}_{3}^{2-}$ to $\mathrm{HCO}_{3}^{-}$at $\mathrm{pH} 6-10$. The addition of $\mathrm{NaCl}$ does not obviously change the zeta potential of both LDHs, but $\mathrm{Na}_{2} \mathrm{CO}_{3}$ reduces the zeta potential and even to the negative value, probably relevant to the re-orientation of some adsorbed carbonate on the surface. All the organic anions investigated can negatively charge LDH particles, which can be attributed to the micellization or self-assembly of adsorbed/exchanged organic anions on the LDH surface although these organic anions have the different composition and structure.

\section{Acknowledgments}

Funding from the Australian Research Council for the ARC Centre of Excellence for Functional Nanomaterials and ARC Discovery project (DP0879769) is gratefully acknowledged. Professors Lu acknowledges the support from the Australian Research Council for his Federation Fellowship.

\section{References}

[1] Z.P. Xu, Q.H. Zeng, G.Q.M. Lu, A.B. Yu, Chem. Eng. Sci. 61 (2006) 1027.

[2] S.J. Choi, J.M. Oh, J.H. Choy, J. Mater. Chem. 18 (2008) 615.

[3] J. Choy, S. Kwak, Y. Jeong, J. Park, Angew. Chem. Int. Ed. 39 (2000) 4042.

[4] J.H. Choy, J.S. Jung, J.M. Oh, M. Park, J. Jeong, Y.K. Kang, O.J. Han, Biomaterials 25 (2004) 3059.
[5] P.S. Braterman, Z.P. Xu, F. Yarberry, in: S.M. Auerbach, K.A. Carrado, P.K. Dutta (Eds.), Handbook of Layered Materials, New York, 2004, p. 373.

[6] F. Cavani, F. Trifiro, A. Vaccari, Catal. Today 11 (1991) 173.

[7] J.M. Oh, S.H. Hwang, J.H. Choy, Solid State Ionics 151 (2002) 285.

[8] Z.P. Xu, G. Stevenson, C.-Q. Lu, G.Q.M. Lu, P. Bartlett, P. Gray, J. Am. Chem. Soc. 128 (2006) 36.

[9] K.W. Leong, MRS Bull. 30 (2005) 640.

[10] Z.P. Xu, T.L. Walker, K.-L. Liu, H.M. Cooper, G.Q.M. Lu, P.F. Bartlett, Inter. J. Nanomed. 2 (2007) 163.

[11] W.M. Kriven, S.Y. Kwak, M.A. Wallig, J. Choy, MRS Bull. 29 (2004) 33.

[12] S.Y. Kwak, Y.J. Jeong, J.S. Park, J.H. Choy, Solid State Ionics 151 (2002) 229

[13] K.M. Tyner, M.S. Roberson, K.A. Berghorn, L. Li, R.F. Gilmour, C.A. Batt, E.P. Giannelis, J. Controlled Release 100 (2004) 399.

[14] K.E. Bremmell, G.J. Jameson, S. Biggs, Colloids Surf. A 146 (1999) 75.

[15] Z.P. Xu, G. Stevenson, C.Q. Lu, G.Q.M. Lu, J. Phys. Chem. B 110 (2006) 16923.

[16] Z.P. Xu, G.Q.M. Lu, Chem. Mater. 17 (2005) 1055.

[17] B.D. Cullity, Elements of X-Ray Diffraction Massachusetts, Addison-Wesley, 1978, p. 278.

[18] J.W. Boclair, P.S. Braterman, Chem. Mater. 11 (1999) 298

[19] M.J. Hernandez-Moreno, M.A. Ulibarri, J.L. Rendon, C.J. Serna, Phys. Chem. Miner. 12 (1985) 34.

[20] K. Nakamoto, Infrared and Raman Spectra of Inorganic and Coordinate Compounds: Part A, Wiley, New York, 1997.

[21] Z.P. Xu, H.C. Zeng, J. Phys. Chem. B 105 (2001) 1743.

[22] R.R. Delgado, M.A. Vidaurre, C.P.D. Pauli, M.A. Ulibarri, M.J. Avena, J. Colloid Interface Sci. 280 (2004) 431

[23] F. Yang, S. Liu, J. Xu, Q. Lan, F. Wei, D. Sun, J. Colloid Interface Sci. 302 (2006) 159.

[24] K.M. Tyner, S.R. Schiffman, E.P. Giannelis, J. Controlled Release 95 (2004) 501.

[25] G. Lagaly, O. Mecking, D. Penner, Colloid Polym. Sci. 279 (2001) 1090.

[26] W.G. Hou, S.E. Song, J. Colloid Interface Sci. 269 (2004) 381.

[27] M.B.J. Roeffaers, B.F. Sels, D. Loos, C. Kohl, K. Mullen, P.A. Jacobs, J. Hofkens, D.E.D. Vos, Chem. Phys. Chem. 6 (2005) 2295.

[28] Y.J. Feng, G.R. Williams, F. Leroux, C. Taviot-Gueho, D. O'Hare, Chem. Mater. 18 (2006) 4312.

[29] F.M. Labajos, V. Rives, M.A. Ulibarri, Spectrosc. Lett. 24 (1991) 499.

[30] Z.P. Xu, P.S. Braterman, J. Phys. Chem. C 111 (2007) 4021

[31] Z.P. Xu, P.S. Braterman, J. Mater. Chem. 13 (2003) 268.

[32] G. Buckton, Interfacial Phenomena in Drug Delivery and Targeting, Harwood Academic Publishers, 1995, pp. 140-150. The hydrophilic index of $-\mathrm{SO}_{4}^{-} \mathrm{Na}^{+}$ (38.7) is much bigger than that of ${ }^{-} \mathrm{COO}^{-} \mathrm{Na}^{+}$(19.1). We thus speculate that $-\mathrm{SO}_{4}^{-}$has a higher affinity for $\mathrm{LDH}$ than $-\mathrm{COO}^{-}$. In addition, our unpublished experiment data show that $\mathrm{C}_{8} \mathrm{H}_{17} \mathrm{SO}_{3}^{-}$can quantitatively replace $\mathrm{Cl}^{-}$in $\mathrm{Mg}_{2} \mathrm{Al}-$ $\mathrm{Cl}-\mathrm{LDH}$ while $\mathrm{C}_{8} \mathrm{H}_{17} \mathrm{COO}^{-}$can only replace part of $\mathrm{Cl}^{-}$in this $\mathrm{LDH}$. 